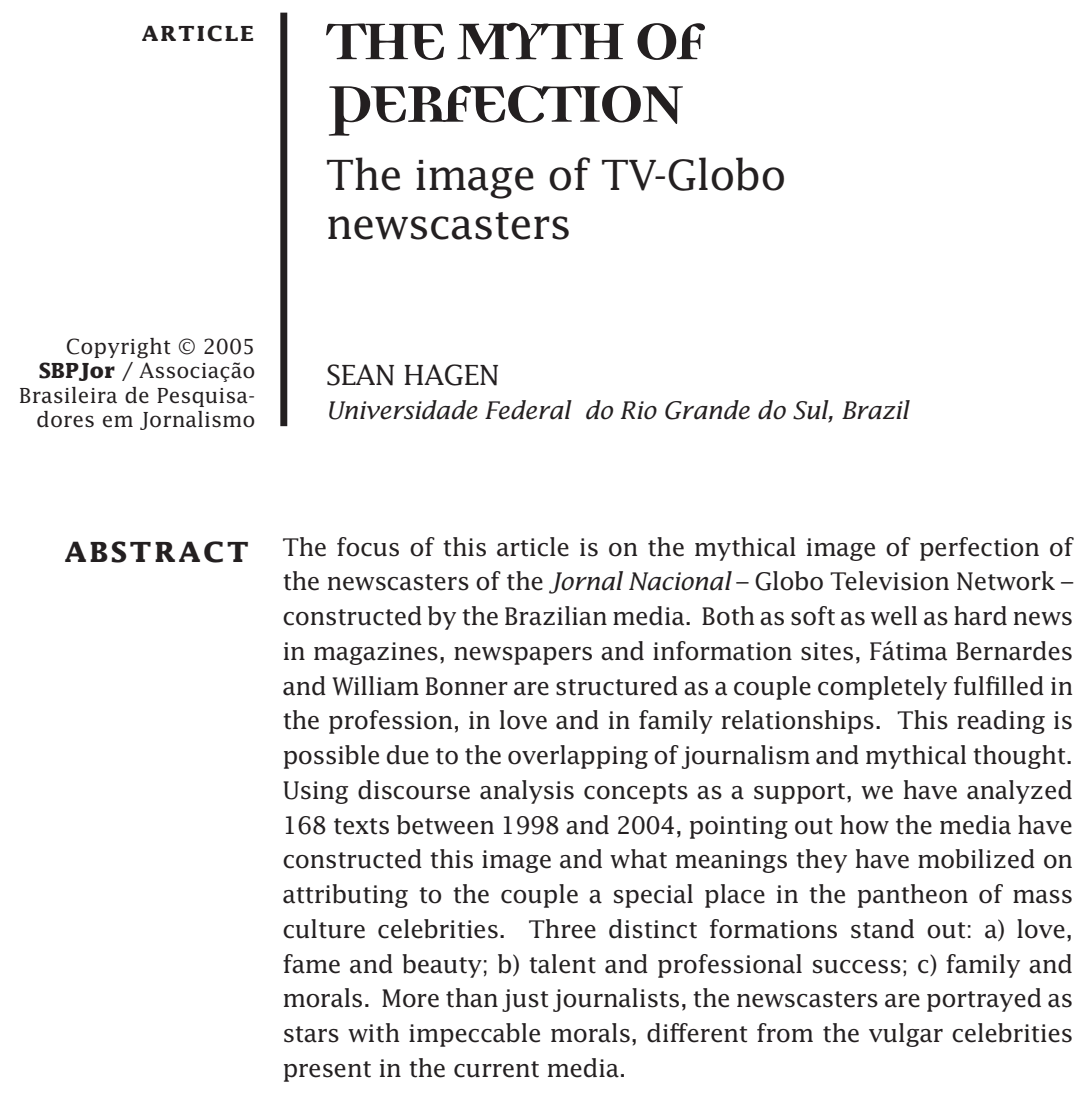

KEY-W ORDS Journalism; myth; discourse; TV Newscasters; Jornal Nacional.

Two journalists of the largest TV network in Brazil meet in the editorial room and get married. Young, good-looking and ambitious, they enjoy relative professional success that enables them to climb up the ranks in the TV station. In their personal life, the birth of triplets, after several attempts at artificial insemination, wins the approval of other media and of the public - that begin to report everything the couple does.

The Globo Television Network, aware that the couple's image is stronger than each one's individual empathy, brings the two of them together at the news desk' of the network's main TV news program and begins the solidification process of a mythical image of perfection, making them part of the excessively mundane universe of 
current celebrities, at the same time that it safeguards their credibility, a vital characteristic for journalism.

What we propose in this article ${ }^{2}$ is that Fátima Bernardes and William Bonner, newscasters of the Jornal Nacionaß (JN) be perceived and analyzed as news, that is, in the same symbolic universe in which they work and express themselves. They cease being the "vehicle" by means of which information is transmitted and become the journalistic "event" itself, since they are portrayed in this way by the media.

TV, on occupying the place of society's main producer of information, takes on a special importance in the production of contemporary meanings. Thus, story-telling - one of the most frequent actions in this electronic medium - can be a way of restoring the pact of faith between journalists and the public: "a new pact that generates credibility implies that TV journalism tells stories that are significant for people's daily life and that the journalist is more a narrator than an informer" (RINCÓN, 2003: 51, our italics).

People now give priority to TV newscasts in order to know what is happening around them. With such importance, television increasingly defines not only what should be seen as information, but itself acquires the status of information, whether it be in other media supports, or by self-endorsement.

On occupying the place of "axis of public information", the spectacle comprising the televised discourse, increasingly invades many TV newscasts at the same time that entertainment programs "disguise" themselves as journalism in order to try to establish an image of credibility - which we call "spectacle journalism". The Jornal Nacional, in the reverse flow of this tendency, follows its trajectory as reference television journalism, professing values that we can classify as "traditional". But even aware of the changes underway - that can be mere passing fads - the JN also presents movements that place it in the time and space in which it is active, focusing one eye on the premises of journalism and the other on the audience numbers and the profits resulting from them. Being a reference newscast both on television as well as in other media supports, the news that the Jornal Nacional transmits has repercussions in the weekly magazines and in the newspapers that also perform reference journalism.

Nevertheless, the JN extrapolated its field of activity and now cannot be seen just as basic to information, but also to the emotion that its newscasters arouse. Fátima Bernardes and William Bonner have ceased to be only journalists that present a TV newscast and have become a 
reference point for a life style, going beyond the journalistic field and entering into the area of myths.

Myth cannot be interpreted only as a legend, an ancient narrative, unreal and static; it should extrapolate the universe of fables and fictions in which it was circumscribed until the end of the XIX century, in order to be seen as something live, that could guarantee meaning and value to the existence of humanity. "[...] the myth' s main function is to reveal exemplary models of all the significant human rites and activities: both nourishment or marriage, as well as work, education, art or wisdom" (ELIADE, 1994: 13). Myth constitutes a living model of conduct, "conferring, for that very reason, meaning and value on existence" (ELIADE, 1994: 8). But it can also be more than one model, it can embody a harmonizing force: "All mythology has to do with the wisdom of life, related to a specific culture, in a specific epoch. It integrates the individual into society and society into the field of nature. It unites the field of nature with my nature" (CAMPBELL, 2003b: 58). From the psychological perspective, myth acquires even more intensity and can be understood as wisdom and meaning loaded with energy and fascination (JUNG, 2002). Dreams and reality, however, should be consonant in order to guarantee the myth's survival, something that the brilliant images of TV and journalism offer in abundance.

Present in an active way in our society, myth passes through all the cultural manifestations and acts above all in the journalistic structure, as well as in the language. More than a model, myth serves to explain all that which "logic" is unable to explain, revealing itself to be a true "interior", a "wisdom" that underlies the search for completeness of the subject.

This is what makes it possible for Bonner to place the Jornal Nacional within Brazilian culture - "[...] an extremely prime time [...] because of the public it reaches" (BONNER apud TEIXEIRA, 2002, web) - and permits the glimpsing of a certain mythical liturgy in the act of daily construction of the TV newscast.

It's not possible to present the entire newscast, then, to reach the end and say, "this is a disgrace". I don't need to say that. I'm not criticizing Boris or whomever does this. It's just another line. The people that watch Boris want to hear his comments. But the "JN" audience is three, five or eight times larger than his. Making the "JN" is not easy. Because it's window glass. Everybody wants to catch me. Magazines, newspapers... (BONNER apud TEIXEIRA, 2001, web) 
Fátima Bernardes converges to Bonner's interdiscourse ${ }^{8}$ on denying gestures that make the presentation a spectacle, but at the same time accepts the mystification of the area occupied:

There aren ' $t$ any comments with catch phrases or phrases of impact, such as we see in some TV newscasts. My mission is not to say that I think something is absurd but to give the public information and bases for reasoning. I give my opinion at a table in the bar, in the supermarket. The news desk is a sacred place. (BERNARDES apud BRASIL, 2002, our boldface).

Without any critical distancing, Bernardes mythicizes the place she occupies legitimating the fascination and the power of projection that she exercises over the TV viewers. The journalist takes over the role she denies playing, in the same way that she says she is "a normal person", but is not portrayed in this way in the printed media - or she does not allow herself to be portrayed. Both Bernardes and Bonner behave like deified movie stars.

From the viewpoint of Bernardes, facing the "sacred" place of the news desk, the newscaster couple has no other choice but to ratify the daily invisible liturgy of devotion to the news, with the due apotheosis and acclaim that this ritual requires. "[...] mythical behavior could be recognized in the obsession for "success", so characteristic of modern society, which translates the dark desire to transcend the limits of the human condition" (ELIADE, 1994: 160). The clichés of success, happiness and adventure, presented by the culture, can never be imitated in their totality, they are models impossible to attain, but nevertheless present in the imagination.

The catalog of images that constitute the common stereotypes of pleasure and duty is the dictionary of the dominant values, the list, not necessarily of the gods to whom we sacrifice ourselves, but of the gods in whose worship we recognize ourselves. The tacit agreement, implicit in these images, cements our social life, and commands a series of choices, naturally (CALLIGARIS, 1996: 58).

Among so many cross references of possible forms of life encountered today, style is at the peak of this manifestation (MAFFESOLI, 1995, 1996). Just as a religion, style is capable of making visible gracefulness that was hidden, bringing to light the truth of a person or object, allowing it to be perceived by everyone. 
Style is the cause and effect of this process. In this case, it permits the recollection that the concrete, the everyday, the banal life without quality, all of these things that were widely made less important in modernity, invert into their opposite [in post-modernity]. Or, more exactly, they give birth to that of which they are the bearers. The spiritual arises from the material (MAFFESOLI, 1995: 46).

Style, "gracefulness" and glamour are predicates that appear galore in the construction of the image of perfection of the newscaster couple found in the press. From this perspective, Bernardes and Bonner are portrayed both in the soft as well as in the hard news as perfect, possessors of an excellence only known by the old movie stars, an unmatched phenomenon within journalism. In different publications we find this same sense ${ }^{9}$ reiterated. The construction of the paraphrase ${ }^{10}$ present in discursive locutions ${ }^{11}$ leads to the image of Bernardes and Bonner structured on the myth of the stars, as if these sequences could be verified:

- [...] journalism stars [...] (GALVÃO..., 2000, web, our boldface)

- William Bonner is penta-champion (reference to Brazil's 5th championship in the World Soccer Cup of 2002), Fátima Bernardes is 5 star (penta-champion ...2002, our boldface).

- Stars have a night of fan worship (STARS..., 2003, p. 14, our boldface).

At the same time that they have sought impartiality and credibility facing the Jornal Nacional news desk, Bernardes and Bonner have had their lives investigated by magazines and newspapers, creating a synergy between these two fields. Getting to know the couple's peculiarities leads our eyes to another reading of the position they occupy as professional journalists: they take on a "humanized" posture in the face of the coldness of the scenario and of technology, they break through the distancing and captivate at the same time that they play a role almost unattainable for the ordinary television viewer. They form a couple that expresses an enviable passion, they are beautiful, charming, exemplary parents and professionally successful. They make all the actions to which they are exposed in the media mythical, regardless of the medium that portrays them.

The changing of reference TV journalism into spectacle can be analyzed, from Maffesoli's viewpoint, by means of the myths of different periods that supplant each other in a slow transmutation. "From this results the fact that the style of the period can be, at the same time, 
"obvious", for those who experience it, and totally opaque, for those who try to analyze it" (MAFFESOLI, 1995: 43).

These are characteristics of the new myth - spectacle-journalism that has been occupying an increasingly large place in TV journalism. But it must be emphasized that these "futile" traits confronted with the area's professional work only acquire resonance when fortified by impartiality, objectivity and credibility, vestiges of reference journalism that serve as substratum of the new myth. In this way, the apparent symbiosis between these two worlds, materialized in the actions of Bernardes and Bonner, expresses the communion that happens in "image-objects", providing the "Eucharist of a new style" (MAFFESOLI, 1995: 129).

The analogy between journalists and celebrities takes us back to the myth of the Hollywood stars in the golden years of the star system ${ }^{12}$, True models for conduct, they developed thanks to "memory becoming bourgeois" (MORIN, 1989: 12), in which the needs and the dreams of the masses are shaped by the society's reigning standard-models. Today, when the childish dreams of yore dissolve in reality, and "the problem of happiness comes after the myth of happiness" (MORIN, 1989: 129), the models that the stars embody already reflect present times. If there is a crisis in modern society, then it is incorporated in the star's day-to-day life: problems with children, family and professional disagreements, bad mood, weaknesses. Whoever manages better the dichotomy between these two worlds has more chances to idolize his image in the media. "Modern stars are models and examples, while the old-fashioned stars were dream ideals" (MORIN, 1989: 119).

At the head of the TV newscast considered by many to be a reference in Brazilian journalism, Fátima Bernardes and William Bonner are constructing a mythical image, in the same way that the stars were formed. On being projected onto another, a "double ${ }^{13}$ ", the couple impregnates the space of the Jornal Nacional with "journalistic talent and a fully successful life", at the same time that it allows itself to be impregnated by the "paradigm of the most famous Brazilian TV newscast", not making it clear where one begins and the other ends. Bernardes and Bonner are the Jornal Nacional, at the same time that the Jornal Nacional is them. Reality and projection begin to share the same space.

The viewer's projection into the hero corresponds to a movement of duplication. This triple unfolding, if it can be said in this way, favors the myth's formation. Its conjugation makes the star blossom on bestowing magic potentialities on the real actor. Going beyond the image, mythical projections concentrate attention on a concrete, 
carnal person: the star. Vested in its double, it is vested by it in turn. The star submerges in the mirror of dreams and emerges in tangible reality (MORIN, 1989: 67).

This is the great difference of Bernardes and Bonner with relation to what Morin (1990) classifies as Olympians-mass culture heroes promoted to stars who have an existence free of necessities; they use work as a form of glorifying their own image. "They live according to the ethics of happiness and pleasure, of the game and the spectacle" (MORIN, 1990: 75). While the newscaster couple shows a perfect existence, without stains - and without "star-like behavior" - practicing absolute values, the Olympians do not shun having their image stained by the exposure to gossip and scandals in the media, as long as this increases the image power that they arduously cultivate.

The construction of the image of Bernardes and Bonner also feeds on what the Olympians have most attuned to the space and time in which they are set - and something that, contradictorily, removed them from the classic conception of myth: the capability of appearing human despite the absolute perfection. The myth embodied by the newscaster couple keeps its feet on the ground while it raises its heart to the heavens. Even constructing an apparently unattainable image, it develops points of contact with the public, avoiding stimulation of a merely fictional construction that could exclude the imaginary with regard to "reality". "In mass culture, the union of the imaginary and the real is much more close that in religious or fairylike myths. The imaginary is not projected to heaven, it remains on earth" (MORIN), 1990: 169).

The public's identification with its idol - "total dreamlike mimicry" (MORIN, 1989: 65) - can help us understand the large number of women and men who straightened their hair, in the entire country, after Fátima Bernardes, revealing that she had used a technique that was little known and tested at the time, appeared with straightened hair on TV. The magazines, newspapers and informative sites gave great emphasis to this banal fact - performed by other women daily - as we can see in the following excerpts:

- In the salons, on the streets, there was only one topic: did you see Fátima's hair? Her short, set hair disappeared from one day to the next. She appeared on TV with faded, limp hair stuck on her head, causing the biggest frisson (ESCORRIDOS..., 2002, Jornal Hoje Maringá, our boldface) 
- [title of the story] The muse and the hair plate - The fans are relieved: Fátima Bernardes' haircut had a happy ending (MARTHE, 2002, Veja, our boldface)

- [...] the newscaster's metamorphosis served to disseminate the capillary revolution that is happening at the moment (MOHERDAUL, 2002, Veja, our boldface).

More than highlighting her own beauty, a predicate inherent in the star, the newscaster distinguished herself as a modern, courageous woman on choosing a procedure that was unprecedented at the time, that did not always guarantee a satisfactory result, despite its high price and the difficulty in applying it. In this way, Bernardes is constructed in the media with the image of a woman in advance of her time.

- Fátima Bernardes innovated again [...] (CONFIRA..., 2003, web, our boldface).

Constructing a life of perfection away from the Jornal Nacional news desk, at the same time that they are portrayed as exemplary professional journalists of the country's most important television new program, the newscasters circulate between two worlds in which the spectacle does not cease to be the keynote. They seek to circumscribe in the television universe a discourse of impartiality, objectivity and credibility without suffocating the glamour of their private life shown in other media.

We recall that the noun "perfection" is employed indiscriminately through common sense and includes such disparate areas as love or the performance of work. Each individual, molded by a culture contained in a time and space, recognizes that which he believes to be "perfect", denoting by means of the symbolic inherent in his personality, inclinations and feelings. It is in the fluid "feeling" that we experience when we come upon something perfect that we want to emphasize the choice for the "modern myth of perfection" made up of Bernardes and Bonner. Based on immemorial definitions, in the encyclopedias, in philosophy or even in common sense, perfection agglutinates definitions and makes feelings potential. Here perfection is not linked just to work, family, beauty or love: perfection is all this sharing the same ambit, creating a consonant - but unique - synergy with the present time. This preferential meaning is what differentiates Bernardes and Bonner from TV/theater/ movie actors or those with other profiles who occupy the place momentarily - of celebrities. While the latter stand out because of only one aspect - professional success, for example - linked to the degree of 
spectacularization that they can add to the reason for their outstanding condition, the newscaster couple shows, in the media, excellence in several sectors, whether professional, amorous or family. On filling in all the spaces, they do not need to create abnormal facts to supply the press: they are myths of perfection with relation to a universe predominantly Olympian and excessively "mundane" - scandals, exaggerations in behavior, constant changing of mates. "Human individuality is affirmed according to a movement in which the aspiration of living in the image of the gods, and of matching them, if possible, participates" (MORIN, 1989: 21).

\section{In search of perfection}

Journalism ${ }^{14}$ as construction of the real, mediated by social and cultural variables, expressed on a discursive base, increasingly makes room for subjectivity and emotion in consonance with objectivity. Mythical constructions begin to assume relevance and legitimate the fact that journalists and public, on accepting the alternation necessary for interaction, share the same "world view". Language, materialized in the journalistic discourse, offers support for these manifestations.

Based on categories defined by Joseph Campbell, we classified the discursive formations present in the 168 texts of our sample, both in the approach to soft as well as hard news in magazines, newspapers and information sites, collected between 1998, the year in which the couple rose to the television news desk, and 2004, at the close of the research. We utilized the classification that Campbell (2003a) recovered from classical Indian mythology to present the three goals that men try to attain in the world and, in a second movement, surpass them.

Kãma is the first goal, designated as "love and pleasure". It is linked to sex and to what this represents: food, safety/shelter, paternity/maternity and to sex itself. Campbell (2003a: 374) recalls that it corresponds to what Freud classified as "basic for all life and thought".

Artha can be defined as "power and success". It is in Nietzsche's philosophy and in Adler's psychology that Campbell (2003a: 375) traces a parallel to show that this second category functions "as the basic impulse and interest in all life and thought, and [...] any psyche completely dominated by this impulse, wishing to conquer, eat, consume and appropriate all things, discovers in myths, gods and religious rituals, nothing more than supernatural means for personal and tribal exaltation". 
Dharma, the "legal order and moral virtue", is the only category entirely linked to culture. As Campbell (2003a: 376) points out, it is "the sense of duty, knowledge of one's own duty and the goal of accepting it and fulfilling it is not innate, but rather an idea instilled in children by education".

There are conflicts and tensions between the categories, as Campbell recalls, and all man's efforts would be to surpass these interests by means of a "disinterested pleasure and the loss of oneself in a rhythm of beauty, today called esthetic and that used to be called, more freely, spiritual, mystic or religious" (CAMPBELL, 2003a: 378).

Our analysis covers the categories in the same structure furnished by Campbell, but expanding a little the universe of interests: Kãma is everything that is linked to sex, beauty, vanity, love and fame. Artha, in turn, will concentrate on the universe relating to work, to journalism, to success, to career and to talent. It is the field of magic and predestination. Dharma includes the manifestations of character, the morals - the family - ethics and cultural ideas. We emphasize that the conflicts among the three discursive formations are incorporated in our analysis; the same sequence can one moment be classified as Dharma, the next as Artha, then as Kãma - and even transit among the three - depending on the position occupied by the subject.

In the Kãma category, we systematize five dominant formations that comprise the meanings expressed in the media. Two - "the muse's perfection" and "emblematic hair" - refer only to Fátima Bernardes. The other three -"the perfection of the beautiful", "fame" and "the couple's ardor" - are common to the two newscasters. Picking out only the main meanings, Bernardes is described as muse, pretty, assured, elegant, lovely, famous, charismatic, likable, stylish, woman with good taste, superstar, star, sexy, celebrity, notorious.

William Bonner is constructed as attractive, simple, naturally elegant, refined, serene, sexy, admired.

In Artha, "talent" and "professional success" are the main meanings highlighted. Here, Bonner is described as serene, assured, talented, competent, victorious (success), worker, powerful, innovator, daring, natural, expert, excellent chief, demanding, comprehending, simple, spontaneous, humble, fearless, charming, balanced, wise, outstanding, firm, consistent, respectable.

Bernardes is portrayed in this category as serene, assured, talented, competent, victorious (success), worker, experienced, capable, unsurpassable, brilliant, sweet, humble, most complete professional 
person in journalism, charming, adorable, good-tempered, outstanding, impeccable, without errors, praiseworthy, modest, luminous, champion, the best, super-powerful, successful, counselor.

In Dharma, two meanings are dominant: "family" and "morals". In the "morals" formation, Bernardes is portrayed as fighter, winner, simple, reliable, modest, discreet, diligent, dedicated, competent, good-tempered, philanthropic, accomplice of her husband, wise.

For Bonner, simplicity, humility, maturity, generosity, modesty, discretion, effort, dedication, competence, good temper, complicity with his wife, kindness, wisdom are highlighted.

With respect to the "family" formation, we opted for presenting the meanings without any differentiation between Bernardes and Bonner, including even the triplets. The family is portrayed then as happy, joyous, persevering, good-tempered, with good parents, with participative parents, playful parents, father and mother devoted full time to their children, affectionate parents, excellent parents, concerned parents, special parents, parents that have special children, parents that have VIP children, parents that have polite children, children that act as the celebration of their parents' marriage.

\section{Perfection}

The exceptional richness of the meanings present in the construction of the image of Fátima Bernardes and William Bonner in the media points to narratives of epic outlines, reaffirming to the readers the presence of seven indispensable moments in the construction of the myth of perfection of the modern star (CAMPBELL, 1997, 2003a, 2003b; MORIN, 1987, 1989, 1990): 1) the story of the origin, in which "destiny", "talent" and "vocation" lead Bernardes and Bonner to the TV news program's newscasters' desk; 2) the glorifying and glorified work of journalists, a place for overcoming difficulties and hurdling obstacles; 3) fame, translated into professional recognition, that extends to success in private life; 4) singularity, the mythological star's element of distinction; 5) the family, pillar and support that makes possible the "eternal return" to the origins; 6) beauty, an edifying trait that confers character to whomever possesses it; and 7) love, the place of the mythological star's maximum expression.

These vehicles do not permit openly dissonant meanings to pass through the myth of perfection bringing depth or dubiousness to the reading. They get entangled in the spiral ${ }^{15}$ of the myth in order to 
incorporate any possible digression that the couple might present. The couple appears unchangeable, always generating the same information. Any new fact incorporated in the mythical spiral acts therefore as confirmation of the primordial image: it changes in order to remain with the same meaning.

The search for completeness in the opposites man/woman, public/ private, family/work is what nourishes the myth of perfection. As androgynous, Bernardes and Bonner are always in search of completeness, never leaving any room for the irruption of emptiness. If in "real" life it is impossible to find perfection, in the media the newscaster couple is a model and a reference, covering all these fields.

- Fátima edits, presents the news and everybody knows that before she still had to put the triplets in school. Fortified with vitamins is very little. These more or less recent victories, won by women with a lot of talent, arrive in the new consolidated generations that no longer perceive they have been the reason for struggling (SANTOS, 2001, Observatório da Imprensa, our boldface)

- Professional, lovely, happily married, good mother. At last, a woman...super-powerful (MARINELLI, 2002, Criativa, our boldface)

- PRETTY, FAMOUS, MOTHER OF TRIPLETS AND VERY HAPPILY MARRIED. Who doesn ' $t$ want to be a little like Fátima Bernardes? (MAGARIAN, 2002, Nova, our boldface)

- Very happily married to William Bonner, with whom she shares the Jornal Nacional news desk and the task of bringing up the three triplets, a journalist reveals the secrets of her happy marriage (DOMINGOS, 2003, Quem, our boldface)

- Have a happy marriage, healthy children and a successful career. Undoubtedly, uniting these three ingredients isn 't easy. For this reason, the story of journalist Fátima Bernardes, age 42, attracts so much attention. The newscaster of the Jornal Nacional knew how to reconcile these three dreams of all women without having to relinquish any one of them in favor of another (TOURINHO, 2004, Ana Maria, our boldface).

If Bernardes is the one who occupies exceptionally an outstanding place in the media, Bonner never fails to be present at all times. In love, in the family or at work, it is Bonner who serves as a reference to construct the success of Bernardes. Even when they are focused separately, the image construction only occurs in the presence of the double, the other "party" of the couple, Yin complementing Yang, the two separated halves in Plato's myth of the androgynous, Adam and Eve born from the same 
body and united again by love. The sense of perfection, however, is very close to being experienced by a large part of the couples in love, which leads the myth of Bernardes and Bonner to incorporate new areas of activity, constructing with the same excellence family and professional relationships. The strength of these senses comes exactly from this indistinctness of three planes that slide over each other pushing the frontier of meaning to a singular interpretation: Bernardes and Bonner are never just perfect newscasters, perfect parents or perfect husband and wife, but they are all these at the same time.

The myth of perfection applies in a more intense way to Bernardes and Bonner because they are not just "empty" celebrities: the fame that they have acquired grows with the success achieved in their work. In a story about professional vocation, the magazine Encontro Importante, concerned with education, reinforced the formation of fame and glamorized even more the newscaster couple of the Jornal Nacional on pointing them out as an example of the difference between success and fame - highlighting them among many other possible examples of professional people. "[...] at the time of choosing a profession, many people pay attention only to the success achieved by the famous. Many aspiring journalists, for example, wish to be as recognized as the journalist couple William Bonner and Fátima Bernardes (AVELINO, 2004, Encontro Importante, our italics). Reporting, anchored in mythical structures, presents an impossible comparison: on one hand the aspiring journalist, in the singular; on the other, a journalist couple, in the plural. No one, alone, could yearn for the fame and the success expressed by the marriage of two people. The image of the "pair" brought out in this sequence points to the myth of the perfection of two beings merged into one, of unattainable plenitude. Bernardes and Bonner enjoy this unequaled fame exactly because it was constructed based on a couple, and not on two separate individuals.

Split into subjects that occupy the place of professional people, parents and lovers apparently at the same time, they encounter the oneness necessary for the coexistence of these three levels in the interpretation of perfection. That is what makes possible the comprehension of a "whole", even if the parts are presented in places that they should not usually occupy. If the sense of perfection of Bernardes and Bonner works on three levels of expression, it becomes "natural" to encounter the children when speaking about work, the profession when speaking about the family or love when defining talent. Perfection is the oxygen that nourishes the meanings constructed by and of the couple. 
Bonner's image, even being constructed with less glamour than that of Bernardes, is nothing more than a reflection of society itself, which glorifies feminine figures more intensely, in accordance with the mass culture of our time.

- Then who's left for us to deify? "Little Fátima", obviously. (HENRIQUE, 2002, Época, our boldface)

- [...] the champion Goddess, Fátima Bernardes (ROCHA, 2002, Diário do Ceará, our boldface).

Since Bonner is not capable of occupying such a glamorized position, the communication media are left with the alternative of constructing an image linked to the work, in which the journalist is described as the "best".

- [Bonner] Symbol of the new image of the TV station [Clobo] in the elections (COHEN, 2002, IstoÉ, our boldface)

- William Bonner was the highlight of the greatest coverage of a presidential race ever made by Brazilian TV (VELLOSO, 2002, Època, our boldface).

The sense of a couple - husband and wife - that is constantly confused with the sense of newscasters, acquires an exceptional reinforcement in the image of mythical love with the arrival of the triplets, with the sense of family overlapping with the two previous senses.

- Fátima Bernardes and William Bonner have proven that husband and wife working together can come out well. The two received the Brazil Quality Award, on the $21 \mathrm{st}$, in the best TV newscaster category. Besides the award, the couple also has other reasons for commemorating: the triplets' sixth birthday [...] (DUPLA..., 2003, Mais Feliz!, our boldface).

With the title of "Double Award", the note, on classifying in the same category Fátima Bernardes/William Bonner, husband/wife, couple/ newscaster, leads the viewers in the direction of the myth of perfection. They are married, work together, are award winners, have triplets, are affectionate and give the same attention to work and to family, achieving success in both areas. As information, what the triplets' birthday adds to the comprehension of the professional talent of Bernardes and Bonner and what the award won by the couple influences their relation with 
their children are not made explicit. But Berrnardes begins a possible answer:

\section{- Whoever knows us knows that we are what people see on television (BERNARDES apud PINHEIRO, 2002, Veja Mulher, our boldface)}

The meaning defined by Bernardes is disseminated by the publications that cover the couple's life; they are an incontrovertible parameter even when objects of criticism.

- [...] Globo insists on fabricating clones, plastic people that have no bad breath, don't become disheveled, for whom the world is an eternal story from "Caras" gossip magazine. They place all their chips on the world of fantasy, in which all couples would be William Bonner and Fátima Bernardes, in a Margarine advertising scenario, feeding smiling, rosy triplets (LIMA, 2002, JT, our boldface)

- We are very much under observation. People see us as the couple that worked out well, a happy family in real life. This creates enormous curiosity (BERNARDES apud PINHEIRO, 2002, Veja Mulher, our boldface).

Bernardes demonstrates that she knows perfectly the distinction that exists between "real" life and the life of "stars", but she does not make any effort to prevent the amalgamation of the two. At the same time that it appears to refute the stardom provided by the media, the couple makes moves in its direction. While we have no information available regarding the existence of a press advisor working for Bernardes and Bonner, the presence of photographers in the most varied environments - luncheonettes, movies, circuses, public squares, vacation spots points to a meticulously fabricated movement, enabling the couple to be portrayed in banal moments in which they expose their private life in a "natural" way. Faced with the power of the myth, it remains for them to accept the idolatry dispensed by the media and provide moments that again nourish the image of perfection.

It is in this contradictory movement that we encounter the Globo Network's differential compared with the growing spectacularization that affects the media. Without the warm affectation of the newscasters in opinionative TV news programs or the exaggerated emotional tone of the announcers in sensationalist programs, the image that Fátima Bernardes and William Bonner construct at the Jornal Nacional news desk is that of 
credibility based on the paradigm of reference TV journalism. In this area, we have an irreproachable posture of the newscasters: on being guided by the ideal of objectivity and impartiality, they construct and consolidate credibility. The brilliant image that stands out on the TV screen is that of professional correctness, and never that of stardom that avails itself of the right to make comments or hand out moral sentences, in a clear attempt to guide the meanings presented to the television viewers.

Without denying the growing spectacularization in journalism, the Jornal Nacional goes along with the times, creating a differentiated style for its newscasters. This movement points to an inversion: when they are on TV - aplace seen as full of spectacle - it is in the performance of their role as newscaster that Bernardes and Bonner occupy the place of the real, being supported and legitimated by the "discourse of truth" present in journalism. Paradoxically, outside the television universe, they construct a spectacular life, exactly what common sense agreed to call "real life". The gala parties, the luxurious clothes, the profusion of nannies and maids, the vacations spent in exotic, paradisiacal places, the unconditional love which they present transform "real life" into a spectacle, glamorizing exactly the area in which the public and the TV newscasters live together in the most balanced way - daily life - since it is from there that journalism draws the raw material for its work. But Bernardes and Bonner subvert the reigning order and make glamorous everything they do non-professionally because they need to deny the glamour that could come "naturally" to their field of work by means of TV's "platinum" rays. The meaning that is deduced is that they lead a spectacular life style exactly because they are too human: despite having everything within reach - and not hiding the fact that they take advantage of this - they consciously opted for being like the most simple viewer.

It is on the harmony of these two fields - real and spectacular - that the myth of perfection is based: simultaneously, journalistic credibility, when incorporated by the newscasters in the news desk of the TV news program, leads the eye to the preferential sense of truth, but does not prevent the glamour and star aura, present outside this area, from meddling with the preferential sense, nourishing and being nourished by it. Playing with the senses of being and not being, showing and hiding, the couple materializes as support for the myth's existence.

In the ambit of media celebrities and famous people, Bernardes and Bonner stand out because they succeed in uniting the traits of Kãma, the field that constitutes Olympian figures, with Artha and Dharma, these being exceptional areas in this universe. The strength of the image of 
perfection induced by the couple affects both the journalists that work in areas that incorporate subjective knowledge of expression - soft news - as well as the professional journalists guided in a more incisive way by an alleged veracity, the result of objectivity - hard news. This is only possible because, on reproducing an imaginary idea that Mythos is separated from Logos, journalism tries to attribute to the discourse it produces a unique incontrovertible truth, bringing its routines closer to the logic and rationality present in the discourse of positivist science. But the myth's strength, like an earthquake that de-structures the knowledge of the real established by society - in a defined time and place - brings to the surface a subjective truth that cannot be ignored, despite its still being little legitimated.

The interesting thing is that this movement, escaping from the prison in which it was confined, adheres precisely to one of the bastions of modern rationality: journalism. Interacting with journalism, the mythical forms, dressed up as information, cease to be something "dreamed of" or "false" and instead acquire the status of news. Thus, with a coating of legitimacy, they cause no surprise in an epoch that opts for rationality, succeeding in turning its spiral on a field that tries to deny it. It is this that permits Bernardes and Bonner to break out of the original place in which they were confined, to be constructed with an image of perfection even in sectors that refute these structures. Even when criticized or pointed to as stars of journalism, their mythical image is not contested at any time, a movement that contributes exceedingly to the nourishment and fixation of the myth.

In only seven years - the period in which they have been heading the Journal Nacional - Bernardes and Bonner have pointed to a trend that can be the tonic of current TV journalism: preserving the place referring to reference journalism, at the same time that they practice glamour in various media sectors. They maintain intact the alleged credibility and objectivity of information, without failing to offer a dose of spectacle. They act on the imagination in which the ancestral nature of mythical forms offers models and values to placate human beings' basic questions that continue unanswered: who we are, how we express ourselves and what relation we create with others. 


\section{NOTES}

1 The news desk is understood here to be the scenario that the television viewer interprets as being the Jornal Nacional.

2 This text is a succinct version of the dissertation "From newscasters to model: the construction of the image of Fátima Bernardes and William Bonner as a myth of perfection", presented in 2004 in the Federal University of Rio Grande do Sul (UFRCS), Brazil.

3 This is the oldest and most influential Brazilian TV newscast. It began in 1969 with the ambition of uniting the extensive territory of Brazil through images and information. It is the TV newscast with the largest audience in the country and with the largest advertising revenues. Despite being considered excessively supportive of the government, it is still the news program with the greatest credibility in Brazil. Bernardes and Bonner have both been JN newscasters since 1998. Bonner has been editor-inchief of the TV newscast since 1999.

4 The event is the primordial moment of journalistic creation, the starting point of signification (RODRICUES, 1993). It has a special character that distinguishes it from other events: banality, vulgarization and repetition destroy the possibility of its occurrence, the "excess" being the most important variable due to the characteristic of abnormality in the functioning of individual or collective bodies. What we postulate is a structure similar to mythical thinking forming and articulating the base of journalistic endeavor. This thinking is formed in the "Anti-Spirit" (MORIN, 1987: 158), at a time in which the brain and the spirit were not yet disassociated, and from where the mythic-symbolic structures act. If the Anti-Spirit declares a belief in "atmospheric, telluric, astrological" signs and in the premise that everything can be expressed in signs, the mythical structure makes the systematic movement of confirmation of this faith.

5 Jesús Gonzáles Requena (1988), in a somewhat deterministic way, defines the dominant television discourse as essentially narcissistic, psychotic, fragmented, de-symbolized, sexual, empty, redundant and self-devouring. He says it is inserted in a spectacular context that functions as a mirror. The programming - a macro discourse - reflects, by means of the programs - a micro discourse - the television viewer who, looking at TV, sees the image created of him, not the image he really possesses. 
6 According to Amaral, post-modernity removed from the center of attention some propositions present in the reference journalistic discourse, but this does not diminish their importance. "Instead of the dominant nihilism and relativism, its discourse is still that of commitment to the truth of events and loyalty to reality. It makes use of a discourse legitimated by is field based on the commitment to the public interest" (AMARAL, 2002: 30).

7 Boris Casoy presents the television newscast of a station that competes with the Globo Network. Coming from the print media, he became famous for exaggerated, grimacing comments and the tone of indignation with which he presented the news.

8 Interdiscourse or discursive memory is that which is revealed before anything is spoken and comes from the founding moment crossing time and space to crystallize in the language: "[...] discursive knowledge which makes it possible to say everything and which returns in the preconstructed form, the already said that is at the base of what can be said, supporting each taking of the floor, interdiscourse makes available sayings that affect the way the subject means in a given discursive situation" ORLANDI, 2001: 31).

9 On performing a qualitative research work circumscribed in a discursive universe, we opted for the discourse analysis method. In this article, we are explaining only those concepts that we appropriated to make the method operational.

10 The paraphrase consists of the act of always repeating the first meaning of the assertion. According to Orlandi (2001: 36), "the paraphrasing processes are those by which in everything said there is always something that is maintained, that is, that which can be said, memory. The paraphrase thus represents the return to the same spaces of the saying. Different formulations of the same sedimentary saying are produced". We recall that this is a function that is also present in mythical thinking.

11 The concept of discursive formation, systematized by Foucault (1995) and Pécheux (1990a, 1990b), permits the pointing out of the discourse's regularities. Dispersion is the key to discourse for Foucault: to understand a discourse, it is necessary to locate, perceive, discern these elements that are not always mutually compatible, difficult to classify, but that appear with regularity in its structuring. This enables pointing to the regularities necessary within the discourse's functioning in order that the meanings are understood. "In the case in which it is possible to describe, among 
a certain number of assertions, a similar system of dispersion, and in the case in which among objects, the types of assertion, the concepts, the thematic choices, a regularity (an order, correlations, positions and functioning, transformations) can be defined, we will say by convention that it is a question of a discursive formation - thus avoiding words too loaded down with conditions and consequences, inappropriate for designating such a dispersion, such as "science", or "ideology", or "theory", or "domain of objectivity" (FOUCAULT, 1995: 43).

12 The star system controlled and glamorized all aspects of the life of the actors portrayed in the media. It transformed ordinary people into models for conduct, impregnated with a mythical aura. This system was in effect from the end of the 20 s until the 50 s in the last century. Regarding this matter, we suggest reading Otto Friedrich (1988).

13 The excellent image with which they are described by the media reinforces the feeling that plenitude is only possible in the uniting of opposites - personified in the image of a couple - but without abandoning the proposition, in the case of Bernardes and Bonner, that the two are presented as perfect in their individual aspects. The androgynous, "symbol of the union" (DURAND, 1997m: 292) between man and woman, carries the sense of perfection present in the Bernardes and Bonner couple. If in the media other than the Jornal Nacional we find the "androgynous" materialized in the perfect couple - Bernardes and Bonner - in which man and woman merge as if they wished to stop the running of time and provide a moment of infinite plenitude, the image they project in the TV newscast takes us back again to reality, placing us in the field of mortality. The figure of the androgynous is present both in oriental culture - as in Yin and Yang - as well as in western culture, by means of the Greek myth of Hermaphrodite or in Plato's "The Banquet". The sense of ambiguity that the androgynous encompasses is nothing more than the base of the myth. In the androgynous, we encounter an intermediation between two opposites, whether in space or in time. It is the being that Lévi-Strauss called "trickster", "[,,,] a mediator, and this function explains why he retains something of the duality that his duty is to overcome. This results in his ambiguous, equivocal character" (1996: 261).

14 Proposing a constant negotiation among the diverse social agents in the production of news, the constructionist theory, to which we adhere, indicates that it is necessary to dissolve tensions and harmonize dualities within the editorial room in order to arrive at the final product, the news. According to this theory, the systematized work routines and the library of news models in which the reporter always finds a 
predefined way of telling his stories, permit journalists to transit more safely in a place of constant conflict between freedom and restriction, the differential and the routine, quality in consonance with the time and the actual performance of the work as opposed to the production costs (TRAQUINA, 2001). It is necessary to understand journalism as a construction based on mediated possibilities, and never on absolute affirmatives. In this way, recovering the real value of the image and of the symbolic in journalistic mediations opens an unusual perspective for comprehension of the area. "[...] the reporter utilizes his conscious, rational mental resources and also unconscious impulses, his most profound mental images. These images project on his consciousness innate universal archetypical representations, sometimes superficially called stereotypes, from which he cannot get away. These images are as if "evoked" by the reporter's consciousness to help him in his effort at interpretation" (MOTTA, 2000:1).

15 The various "layers" that comprise the myth, with the repetition of sequences and variations in its narrative, help to "[...] furnish a logical model for resolving a contradiction (an impossible task, when the contradiction is real) [...]. The myth develops as a spiral, until the intellectual impulse that produced it is exhausted" (LÉVI-STRAUSS, 1996: 264-265).

\section{BIBLIOGRAPHY}

AMARAL, M. F. Matrizes culturais do segmento popular da grande imprensa. Ecos Revista, Pelotas, n. 6, p. 27-50, Jan.-June. 2002.

ASTROS vivem noite de tietes. Viva mais!, n. 199, p. 14, June 18, 2003.

AVELINO, L. Ó dúvida cruel. Encontro Importante, n. 27, May. 2004. Available at: http://www.revistaencontro.com.br/maio04/educacao. asp. Access on May: 20,. 2004.

BRASIL, R. Delicado equilíbrio. Zero Hora, p. 6, April 14,. 2002

CALLIGARIS, C. Crônicas do individualismo cotidiano. São Paulo: Ática, 1996.

CAMPBELL, J. O herói de mil faces. São Paulo: Cultrix/Pensamento, 1997.

CAMPBELL, J. As máscaras de Deus: mitologia primitiva. 6. ed. São Paulo: Palas Athena, 2003a

CAMPBELL, J. O poder do mito. 21. ed. São Paulo: Palas Athena, 2003b. 
COEHN, V. A nova cara do jornalismo da Globo. IstoÉ Gente, ed. 169, Oct. 28, 2002. Available at: http://www.terra.com.br.istoegente/169/ reportagens/william bonner.htm.Access on March 23,. 2003.

CONFIRA o novo visual de Fátima Bernardes no comando do Jornal Nacional. O Babado, Aug. 4,. 2003. Available at: http://babado.ig.com. br/materias/156001-156500/156368_1.html. Access on: Aug; 9, 2003.

DOMINGOS, D. A apaixonada Fátima Bernardes. Quem Acontece. Available at: $\quad$ http://www.revistaquem.globo.com/Quem/0,6993,EQG4893672157-2,00.html. Access on: July 4, 2003.

DUPLA Premiação. Mais Feliz!, n. 50, p. 6, 31 out. 2003.

DURAND, G. As estruturas antropológicas do imaginário. São Paulo: Martins Fontes, 1997.

ELIADE, M. Mito e realidade. 4. ed. São Paulo: Perspectiva, 1994.

ESCORRIDOS na marra. Hoje Maringá, 2002. Available at: http://www. hojemaringa.com.Br/vida/belezal.htm. Access on: May 25,. 2003.

FOUCAULT, M. A arqueologia do saber. 4. ed. Rio de Janeiro: Forense Universitária, 1995.

FRIEDRICH, O. A cidade das redes: Hollywood nos anos 40. São Paulo: Companhia das Letras, 1988.

GALVÃO Bueno, bem amigo da Rede Globo. Estadão.com, 27 ago. 2000. Available at: http://www.jt.estadao.com.br/suplementos/ catv/2000/08/27/catv030.html. Access on: July 18, 2003.

HENRIQUE, C. Quem já sai campeão da Ásia. Época, 15 mai. [?] 2002. Available at: http://epoca.globo.com/especiais online/2002/05/15 copa/claudio05.htm. Access on: Nov. 26, 2002.

JUNG, C. G.(org.). O homem e seus símbolos. Rio de Janeiro: Nova Fronteira, 2002.

LÉVI-STRAUSS, C. Antropologia estrutural. 5 ed., Rio de Janeiro: Tempo Brasileiro, 1996.

LIMA, P. Silvio Santos agita a mídia, para o bem e para o mal (2). Jornal da Tarde, April 9,. 2002. Available at: http://txt.jt.com.br/ editorias/2002/04/09/var037.html. Access on: Jan. 11, 2003.

MAFFESOLI, M. A Contemplação do mundo. Porto Alegre: Artes e Ofícios, 1995.

MAGARIAN, D. Paixão nacional. Nova, São Paulo, ano 30, n. 9, p. 130-133, Sept.. 2002.

MARINELLI, F. Superpoderosa. Criativa, n.156, p. 10-13, April 2002.

MARTHE, M. A musa e a chapinha. Veja, Aug; 28,. 2002. Available at: http:// veja.abril.com.br/280802/p 106.html. Access on: Aug; 30, 2002. 
MOHERDAUI, B. Revolução da chapa. Veja, Sept. 25,. 2002. Available at: http://veja.abril.uol.com.br/250902/p 070.html. Access on: Sept. 13, 2003.

MORIN, E. O método III: o conhecimento do conhecimento. Lisboa: EuropaAmérica, 1987.

MORIN, E. As estrelas: mito e sedução no cinema. Rio de Janeiro: José Olímpio, 1989.

MORIN, E. Cultura de Massas no Século XX: Neurose. 8. ed. Rio de Janeiro: Forense Universitária, 1990.

MOTTA, L G. A psicanálise do texto: a mídia e a reprodução do mito na sociedade contemporânea. In: $9^{\circ}$ Encontro Anual da Associação Nacional de Programas de Pós-Graduação em Comunicação, 2000, Porto Alegre. Anais. Porto Alegre: Compós, p. 1-11, 2000.

ORLANDI, E. Análise do discurso: princípios e procedimentos. 3. ed. Campinas: Pontes, 2001.

PÊCHEUX, M. Análise de discurso: três épocas. In: GADET, F; HANK, Tony (orgs.). Por uma análise automática do discurso: uma introdução à obra de M. Pêcheux. Campinas: Unicamp, p. 285-294, 1990a.

PÊCHEUX, M; FUCHS, C. A propósito da Análise Automática do Discurso: atualização e perspectivas. In: GADET, Françoise; HANK, Tony (orgs.). Por uma Análise Automática do Discurso: uma introdução à obra de Michel Pêcheux. Campinas: Unicamp, 1990b.

PENTA não, cinco estrelas. O Estado de São Paulo, July 1, 2002. Available at: http://www.jt.estadao.com.br/editorias/2002/07/01 esp073.html. Access on: July 18, 2003.

PINHEIRO, D. Juntos, 24 horas por dia. Veja Mulher, Aug. 2002. Available at: http://veja.abril.uol.com.br/especiais/mulher2/entrevista.html. Access on: Jan. 7, 2003.

REQUENA, J. G. El Discurso Televisivo: espetáculo de la posmodernidad. Madrid: Ediciones Catedra, 1988.

RINCÓN, O. Hacia un nuevo periodismo televisivo. Revista Diálogos de la comunicación, México, n. 66. p. 46-57, June 2003.

ROCHA, A. Fátima Bernardes, o melhor da Copa. Diário do Ceará, 22 jun. 2002. Disponível em: http://www.noolhar.com/opovo/people/150690. html. Acesso em: 04 jul. 2003.

RODRIGUES, A. D. O acontecimento. In: TRAQUINA, Nelson (org.). Jornalismo: questões, teorias e "estórias". Lisboa: Vega, 1993.

SANTOS, J. F. dos. Mulheres. Observatório da Imprensa, March 14, 2001. Available at: http://observatorio.ultimosegundo.ig.com.br/artigos/ qtv140320016.htm. Access on: March 22, 2003. 
TEIXEIRA, R. Segundo tempo. Correio Braziliense, Sept. 22, 2002. Available at: http://www2.correioweb.com.br/cwEDICAO 20020922/sup ctv 220902 47.htm. Access on: Nov. 26, 2002.

TEIXEIRA, R. William Bonner completa dois anos como editor-chefe do "Jornal Nacional", líder de audiência. AN, no Formato da Notícia, Sept. 4, 2001. Available at: http://an.uol.com.br/2001/set/04/0tev.httm. Access on: Nov. 26, 2002.

TOURINHO, B. A receita do sucesso. Ana Maria, n. 399, p. 10-12, June 4, 2004.

TRAQUINA, N. O estudo do jornalismo no século XX. São Leopoldo: Unisinos, 2001.

VELlOSO, B. Surpresa no ar. Época, ed. 232, Oct. 28, 2002. Available at: http://revistaepoca.globo.com/epoca/0, EPT427335-2011,00.html. Access on: Oct. 30, 2002.

Sean Hagen is a journalist, a Masters Degree in the Communication and Information Program of the Federal University of Rio Grande do Sul (PPGCOM/UFRGS), Brazil, and a Doctorate student in the PPGCOM/ UFRGS. 